\title{
Swedish Schools and Gender Equality in the 1970s
}

\author{
Maria Hedlin ${ }^{1}$ \\ ${ }^{1}$ School of Education and Behavioural Sciences, University of Borås, Sweden \\ Correspondence: Maria Hedlin, School of Education and Behavioural Sciences, University of Borås, SE-50190 \\ Borås, Sweden. E-mail: maria.hedlin@hb.se/maria.hedlin@lnu.se
}

Received: December 17, 2012 Accepted: January 4, 2013 Online Published: January 27, 2013

doi:10.5539/ies.v6n3p76 URL: http://dx.doi.org/10.5539/ies.v6n3p76

\begin{abstract}
In Sweden, as in many countries before Sweden, boys' academic achievements are getting considerable attention as the big gender issue. The Swedish gender equality policy that was put on the agenda in the 1970s is now associated with extreme discussions. This study aims to explore how gender equality was discussed in the 1970s, in connection with work on a forthcoming curriculum. The empirical material examined consists of the preparatory work for the Swedish comprehensive school National Curriculum, LGR 80 and the publication Lärartidningen [Teachers' Journal]. In the material, the gender inequality problem was first and foremost discussed in terms of sex-role values that led to sex-linked choices of education and jobs. Hopes that girls would turn to technical education and technical career choices were highly connected to the issue of equality between the sexes. Attention was occasionally drawn to women's second-rate position in society, but mainly the problem of gender inequality was considered to be pupils' attitudes rather than structures and strong cultural norms. Through information and sex-mixed classes the problem would be solved. Thus, in the material examined the gender discussions were rather superficial.
\end{abstract}

Keywords: gender equality, femininities, masculinities, compulsory school, educational policy

\section{Introduction}

Sweden has a reputation as being world-leading on gender equality (Pringle, 2009; Towns, 2002; Weiner, 2005). Recently, however, the focus in gender equality policy has shifted. In September 2012, Nyamko Sabuni, Minister for Gender Equality and Deputy Minister for Education, announced that girls and women have been at the center of attention for a long time, and now it is time to put the focus on boys and men (Utbildningsdepartementet, 2012). One issue that needs attention from a gender equality perspective is boys' lower academic achievement compared to girls', the minister claimed. To understand this shift, I will go back to the Swedish gender equality discussions of the 1970s.

Internationally the focus on boys is well known. The discourse of "successful girls versus failing boys" started in Britain in the 1990s and has spread across the Western world (Foster, Kimmel, \& Skelton 2001; Zyngier, 2009). This view has been criticized for being based on simplistic notions on gender and learning as well as for reinforcing gender stereotypes (Martino \& Berill, 2003). Nevertheless this travelling discourse has been repeated in one country after another; but compared with other countries, it arrived late in Sweden. At the millennium shift the Swedish researcher Öhrn (2000) noted that Sweden was not affected by the "moral panic" going on elsewhere about boys' underachievement. Although Swedish girls as a group got higher grades than boys as a group, this had not caused much distress. A suggested explanation was that Swedish girls had performed better than boys for decades and the pattern therefore was well known. Girls' academic performance did not give them a privileged position, neither on the labour market nor in society as a whole. Also girls did often not use their good grades to apply for high status education (Elgqvist Saltzman, 1992). A few years later, however, the discussions had taken a different turn. The attention when discussing gender issues was turned to boys' academic performance (Arnesen, Lahelma, \& Öhrn, 2008). In 2012, with the above-mentioned announcement by the Minister, a new course clearly entered in the Swedish gender equality policy.

The gender policy that Sweden is so famous for was established in the mid-1970s. Florin and Nilsson (1999) have studied how gender issues were promoted by journalists, scholars, politicians and officials who often collaborated. Thanks to a few dedicated pioneers, radical gender equality goals for schools were stated as early as the national curriculum of 1969 (Nilsson, 2008). When the nine-year comprehensive school system was 
introduced in 1962, men as breadwinners and women as homemakers was still a strong ideal, but in 1969, by the comprehensive school's first reform, this ideal was to be questioned (Baude, 1979; LGR 69). However, by the next reform, in the national curriculum of 1980 (LGR 80), the formulations about gender equality were de-emphasized (Elgvist Saltzman, 1991).

Lately the gender equality discussions of the 1970s have been called exaggerated. The women and men who engaged in the work for gender equality are associated with fanaticism and ridiculous behavior (Hill, 2007; Sillen et al., 2010). The words gender equality and gender roles may trigger malicious debates (Hedlin 2012; Wahl et al., 2008). The gender discussions of the 1970s are dismissed and said to have been characterized by extreme ideas (Amundsdotter, 2010; Egeland, 2001; Sjögren, 2003). But how extreme were the discussions about schools and gender equality?

In this paper I will explore how gender equality was discussed in relation to the Swedish comprehensive school during the period when the Swedish comprehensive school's second curricula reform was forthcoming.

\section{The Swedish Context}

In 1961 a great sex-role debate started in Sweden (Lundqvist, 1999). The demand for a change concerning sex roles was taken up by cultural workers, journalists, young intellectuals, public officials and politicians. Also, Scandinavian research on sex roles became wide-spread and contributed to the discussions. A new Swedish concept, jämställdhet [gender equality], appeared on the political agenda (Florin \& Nilsson, 1999; Lundqvist \& Roman, 2008). The discussions led to new policies and legislation. Many of them aimed directly at strengthening the women's position in the labour market. In the 1970s the Swedish labour market was still highly gender-segregated. In fact, it was claimed that Sweden had two separate labour markets, one larger for men and one smaller for women. Most women were employed in the health care sector, in retail trade, as teachers or in offices. The men working in these sectors were often doing different types of jobs compared with their female colleagues. This distribution of chores and jobs was in direct conflict with the new ideal of jämställdhet, or equality between the sexes, as the concept was translated to English at that time (Liljeström et al., 1975).

Furthermore, many women had low income jobs and women generally had a weak position in the labour market. At the same time, there was a shortage of labour in traditional masculine sectors, such as the engineering industry. In the beginning of the 1970s this shortage was expected to increase (Liljeström et al., 1975). Given the actual and expected labour shortage within the industry sector, women and especially housewives came to be regarded as an untapped labour supply (Baude, 1979). Programmes aiming at recruiting women to "male jobs" were launched (Liljeström et al., 1975).

Female employment was also promoted by measures such as the introduction of husband's and wife's separate taxation, and expansion of public child care and preschools (Lewis \& Åström, 1992). The female employment rates rose. From being 60 percent in 1970, it increased to 69 percent in 1975 . The male employment rate increased from 90 to 91 percent in the same period (SOU 2005:66).

The situation in Sweden outlined above is an important background framing this study of how gender issues were discussed in relation to comprehensive school. Below, I will describe the theoretical point of departure, the empirical material and the research question of the present study.

\section{The Present Study}

In this study, I draw on Connell's (2009) theory of gender as a category for attributing meaning and organizing social relations. Connell identifies four dimensions of gender relations. An analysis of gender and gendered relations can be conducted by examining the practices in these dimensions. The symbolic dimension refers to all the ideas that are connected to the gender categories. Whenever we speak of "a woman" or "a man" we call into play a system of notions, understandings and expectations, as Connell explains. We often interpret gender differences in terms of oppositions instead of overlapping aspects. For instance, man is associated with being active and woman with being passive. In school men teachers are associated with discipline and women teachers with care. These kinds of notions can be very strong, although we know that men may well be caring and likewise women may be tough on discipline. The emotional dimension includes romance and sexual desire, but also feelings and emotional commitment of gendered character. For instance, men are usually permitted to express anger in a way that does not apply to women, whereas women are more allowed to express sorrow and pain. Furthermore, feelings concerning gender norms can be very strong, and violation of gender norms may evoke anger, even rage. The productive dimension concerns the division of labour. Tasks, jobs, workplaces and trades are gendered. In education, for example, many school subjects and programmes are associated with femininity or masculinity. The power dimension refers both to institutionalized authority and more diffuse 
discursive hierarchies and to access to resources. Moreover, the dimension includes the subordination of women and the dominance of men as a general pattern in society.

The empirical material examined consists of the School Commission report, Government Bills and Parliamentary Motions that constitute the preparatory work for the Swedish comprehensive school National Curriculum, LGR 80. Subsequent political discussions that took place in the Parliament are also included. The preparatory documents start with the report of the SIA School Commission, SOU 1974:53. The SIA Commission was appointed largely due to school discipline problems. When the commission had published its report of nearly 1000 pages, two Government Bills followed, Proposition 1975/76:39 and Proposition 1978/79:180. The bills also account for opinions from a lot of referral bodies. These opinions are both reported and quoted, and are thus part of the empirical material. After each of the bills, parliamentary motions followed. These motions are considered preparatory work as well. The bills and the motions were discussed in the debates in parliament. The minutes of these discussions are thus included in the material.

In addition, the Teachers' Union publication Lärartidningen [Teachers' Journal], Ltg for short, the weekly union publication that concerns most of the teachers in comprehensive school, is added to the preparatory documents. The annual volumes 1975-1980 are included in the empirical material. (Appendix 1).

The empirical material is explored with respect to how the gender equality issues were discussed. At the time the official translation of jämställdhet to English was equality between the sexes or equality between men and women (See e.g. Liljeström et al., 1975). Therefore these expressions will be used. The focus is on the discussions. Hence, the different actors will often be mentioned in general terms, a referral organization, a parliamentary motion, a teacher being interviewed in Teachers' Journal, et cetera. Quotes have been translated from Swedish by the author.

The aim of the study is to explore how gender equality was discussed in the 1970s, or rather during the period when the Swedish comprehensive school's second curricula reform was forthcoming. Issues concerning pupils are at the centre of interest and the research question put to the material is: How were the gender equality problems and the solutions discussed?

\section{Equality between the Sexes}

In the subsequent sections an account of the empirical analysis is given. In the material equality between the sexes was discussed in relation to four issues. Mainly, there was a strong focus on pupils' erroneous attitudes. First, there was a discussion concerning choices of activities. The need to counteract the pupils' sex-role thinking when choosing activities was stressed. Second, four specific school subjects were considered important in the mission to counteract pupils' sex-role thinking. These subjects were home economics, physical education, crafts and technology. Third, promoting equality between the sexes was discussed as a matter of counteracting pupils' sex-bound educational and career choices. Not all discussions, however, were concentrating on pupils' sex-role thinking. As a fourth issue, efforts were made to highlight the problems in society at large. Strong norms and notions that have great influence on both teachers and pupils, such as women's second-rate position in society, were addressed. Below, the four issues will be described.

\subsection{Counteracting Pupils' Sex-Role Thinking When Choosing Activities}

In the early 1970s there was an intense debate about the problems in Swedish schools. The reform of 1969 had made the school more uniform and more theoretical. The new orientation was criticized for poorly suiting many pupils; especially the pupils unmotivated by theoretical studies were suffering. A commission was appointed to investigate the major discipline problems and the unsatisfactory work environment for both pupils and teachers (Lundgren, 1999; Marklund, 1983; SOU 1974:53). The report Skolans arbetsmiljö [The work environment in schools] includes an account of many studies on girls' and boys' academic achievements, their orientations of interests, adjustment problems and dropout rates, et cetera. Regarding the disciplinary problems and the work environment, the commission concludes that schools must work more on satisfaction and preventive measures to tackle shortcomings in motivation and discipline. The report suggests that schools co-operate with different types of organizations and together with them offer activities in between and after classes. The aim is that education will be perceived more positively if pupils are offered activities that match their personal interests and choices.

In this context, the question of equality between the sexes is brought to the fore. In the report it is claimed that sex-role thinking must be counteracted. There is a risk that pupils choose activities routinely, for example, according to sex roles. Therefore, it is stressed that both school staff and organizations involved must inform pupils about the different options offered (SOU 1974:53, p. 274). That free choices of activities and optional subjects are contrasted against pupils' traditional sex-role thinking is underscored in the Government Bill which 
addresses the commission report. Both the government and referral bodies commenting on the report express themselves in a similar way. The Minister of Schools stresses that the activities must be planned in a way that counteracts traditional sex-role values (Proposition 1975/76:39, p. 259). A liberal woman's organization comments that pupils must have a free choice, which is contrasted with traditional sex-role thinking:

FBF strongly emphasizes the need to give opportunities for both girls and boys to choose free and voluntary activities after their interest and aptitude, so that traditional sex-role thinking does not persist (Proposition 1975/76:39, p. 40).

\subsection{Four Subjects Important for Counteracting Pupils'Sex-Roles}

The issue of equality between the sexes is also addressed in relation to school subjects in the ordinary teaching. Home economics, physical education, crafts and technology are four subjects that are considered important for counteracting sex roles. When these subjects are addressed discussions are often more concrete. In the Government Bill that is presented in 1979 it is argued that home economics is a subject that gives everyday training in equality between the sexes with boys and girls together, planning, allocating and performing various tasks that belong in a household (Proposition 1978/79:180, p. 132). The new proposal is therefore for home economics to be introduced in the early years of primary schools. The proposal is highlighted in a motion in Parliament. In the motion it is argued that efforts to prevent pupils' sex-biased educational choices must begin early. Children's sex-role values can be influenced in a positive direction if boys and girls together train practical skills needed in everyday life, and if they also mutually gain insight into family matters and consumer issues. It is claimed that this impact will increase their opportunities for not making sex-specific choices in secondary school (Motion 1978/79:2631).

The work of a sex-role project within the National Board of Education results in a report with suggestions aimed at equality between boys and girls. The report, the project and National Board of Education's discussions are reported in the Teachers' Journal (See for example Ltg 41-1975, pp. 18-23; Ltg 47-1975, pp. 2-3; Ltg 6-1976, pp. 18-50; Ltg 33-1977, pp. 34-35; Ltg 1-1978, p. 15; Ltg 14-1979, p. 27). An important principle is that all teaching groups should be as sex-mixed as possible. The National Board of Education has suggested in line with this principle that sex-segregated groups in physical education should be abolished. Instead, girls and boys in all age groups should have physical education together. The proposal has fallen on fertile ground. The Government states that physical education should be co-education whenever it is possible. Only occasionally, in connection with special exercises might single-sex groups be used (Proposition 1978/79:180, p. 72). Several referral bodies stress that co-educational physical education is an important means to equalize sex roles. It is claimed that co-education in all ages would improve understanding between the sexes. Moreover, co-educational physical education is said to be an obvious requirement from a perspective of equality between the sexes (Proposition 1978/79:180, p. 209).

A similar proposal which is supposed to lead to greater equality between the sexes concerns crafts. For secondary school, all pupils choose either textile craft or woodwork. The majority of all girls choose textile craft and most of the boys choose woodwork. Hence, the choices tend to result in single-sex groups. Since sex-segregated groups are viewed negatively, the National Board of Education has suggested that the choice of crafts should be abolished. Instead, girls and boys shall be taught both textile craft and woodwork together. However, this proposal has not received as positive response as the proposal concerning co-education in physical education. In spite of the pupils' choices of crafts resulting in sex-segregated groups, the government does not want to make any changes. The Minister of Schools says that notions concerning sex roles are particularly strong in the area of crafts: "In no other area, are sex-role values as strong as when it comes to work with soft (textile) and hard (wood) objects" (Proposition 1978/79:180, p. 57). Nevertheless, the proposal is rejected and in this connection, the word "force" is used. To use force is not an option. The Minister of Schools says:

I am well aware that sex-role beliefs are very strong in this area. Yet, I think that at this moment it is not possible to use force to make a change in such a way that all pupils even at secondary school should be required to devote equal time to both types of crafts (Proposition 1978/79:180, p. 18).

Many referral bodies commenting on the proposal of co-education in crafts are positive. Others are hesitant or negative. The time is not ripe. The suggestion is perceived as being too radical. It would lead to excessive problems with order and discipline (Proposition 1978/79:180, pp. 206-207). A municipality writes that co-education in crafts certainly would entail a more comprehensive and equitable school, but it is feared that the problems would be too great, "especially with the boys who would be forced to take textile crafts" (Proposition 1978/79:180, p. 207). 
Technology is another subject in which getting away from single-sex groups is desired. In this context no one talks of force. On the contrary, school technology is associated with freedom and other positive values, at least for the girls' part. Technology has been an optional subject, which almost exclusively has been chosen by boys. Now it is suggested that technology will become a compulsory subject for all pupils in secondary school (Ltg 14-1979, p. 27). This proposal has gained wide acceptance. The matter of equality between the sexes is highlighted by the referral bodies when technology is discussed. One organisation commenting on the proposal argues that the technology subject can contribute to counteract traditional sex-role patterns. A municipality states in its comments that girls in the future would gain knowledge that should be every person's property (Proposition 1978/79:180, p. 239). In the Parliamentary debate, one Member of the Parliament claims that turning technology into a mandatory subject might result in occupational choices being less sex-bound in the future (Minutes June 5, 1979, p. 115). A trade union points out that the school technology is important for society's aspirations for greater equality between the sexes. Being taught technology might liberate girls:

Both girls and boys should broaden their technical knowhow. Girls also need this to make freer choices of occupations and to adopt a more liberated approach to technical and scientific education (Proposition 1978/79:180, p. 239).

\subsection{Counteracting Pupils' Sex-Bound Educational and Career Choices}

In the discussions concerning equality between the sexes, focus is often strong on pupils' educational and vocational choices. That pupils get a lot of contact with the labour market is an important issue generally at this time. It is also emphasized that pupils should be encouraged to be critical of men's and women's roles in the labour market (Motion 1978/79: 2606, pp. 26-28). The government points out that educational and vocational orientation should help ensure that pupils develop their personalities, their talents and interests in order to find for themselves appropriate education and occupations. Educational and vocational guidance "shall thus counteract traditional educational and career choices that are results of social and sex-related factors" (Proposition 1975/76:39, p. 279).

In practice, discussions about non-traditional choices often refer to a wish that girls will choose technical careers. There is a desire to abolish the sex segregation in the technical field. In the Teachers' Journal it is reported that a Council on Equality between Men and Women tries to "amend the absolute male dominance concerning technical jobs" (Ltg 1-1975, p. 7). However, being female in technical jobs does not seem to be very appealing. This is apparent in a description of the council efforts to deal with the male dominance. A questionnaire inquiry addressed to girls attending a four-year engineering programme at upper secondary school has started. The girls' experiences will be collected. Thereafter, a smaller group of these girls will be used as a reference group. When this reference group is ready for the labour market, the council will follow the group and their efforts. It is also planned that employers will be influenced and the girls will get support. The formulations about employers being influenced and the girls being supported refer to the particular problems confronting female engineers both in their education and in the labour market. In the article it says that girls who have chosen technical training, have had difficulties getting practical training at workplaces, with the result that they often drop out. If they do succeed in working as technicians, they have a hard time making their opinions and rights recognized. "They need to stay one step ahead of their male colleagues, and they are often met with mistrust by employers" (Ltg 1-1975, p. 7). The few girls entering the workshop training programme in secondary school also have a hard time with their male peers. According to an article in the Teachers' Journal, they risk being met with mockery and mistrust (Ltg 17-1977, pp. 4-5).

Nevertheless, politicians put great emphasis on the educational and vocational guidance to come to terms with the segregation into male and female in education and employment. It is therefore proposed that the practical occupational guidance, when pupils leave school to practice at various work places, should be organised so that the boys will gain insight into female-dominated occupations and girls into male-dominated (Proposition 1978/79:180, p. 101). Another way to influence future career choices and to counteract traditional choices is to invite parents who have atypical jobs to come to school and talk about their work. In a report in Teachers' Journal on schools' work on equality between the sexes, this measure is mentioned, with a female car mechanic used as an example of what an atypical job might be (Ltg 19-1980, p. 26).

As mentioned above, it is not always easy for girls who choose male-dominated jobs. Companies are not always interested in employing females. Their male fellow pupils might also object. In a survey aimed at boys taking technology as an optional subject, the boys have been asked whether they think it is appropriate for a girl who is technically-minded to train for car mechanic. A quarter of the boys in the survey answered 'no' (Ltg 4-1976, p. 51). Still, the female car mechanic stands out as the paragon of a person who transgresses the segregation in the 
labour market. Another paragon is the girl who is an industrial worker. These two symbols are shown in pictures in Teachers' Journal. A photo of a young female car mechanic is used to show working life in connection with a proposal that work experience will be required for admission to teacher education (Ltg 31-1976, p. 1). A girl in overalls, working together with a man in a workshop, is illustrating the topic of changing sex-roles (Ltg 41-1975 pp. 18-19). A photo of a woman on a scooter in an industrial hall illustrates the needs of manpower in technical and scientific areas (Ltg 6-1976, p. 37). A project with women at "men's jobs" is described as a success, and a girl working in an assembly plant adds to the message (Ltg 10-1977, pp. 24-25). An article that addresses the importance of discussing education and careers with pupils contains a photo of a young woman at a machine in some kind of engineering industry (Ltg 6-1976, pp. 30-31). Another example is demonstrated when the journal refers to a legislative proposal about inequality between men and women in the labour market. The legislative proposal has been published in a book and the cover of the book shows a young woman dressed in overalls, in an engineering industry setting (Ltg 18-1978, p. 8).

Furthermore, it has been suggested that the admissions rules for upper secondary school would be changed. According to the suggestion, pupils applying for an education programme in which they would be in a minority position regarding sex, would receive extra credits. In this case, "minority" refers to being less than 30 percent of either female or male pupils admitted at the last admission. In this context, the government has declared the intention that credits will be of less importance in the future. A Member of the Parliament protests in the Parliament debate. He talks about escapes from reality which include talk of "credits as something unjust and sex quotas as righteous" (Minutes June 5, 1979, p. 95). Generally, however, the proposed admission rules about extra credits concerning minority sex have been received positively. When it is discussed in the Government bill, the two-year workshop training programme (verkstadslinje), an educational option that hardly any girls, and not very many boys either, apply for, is used to illustrate how the suggested admission rules would function.

A girl applies for the two-year workshop training programme, for instance. If less than $30 \%$ of girls got admitted throughout the country, at the last admission, she gets credits for her application (Proposition 1978/79:180, p. 260).

If the girl being an industrial worker or car mechanic is the female paragon of the pupil who chooses something untraditional, the boy in the health care sector is the male equivalent. The boy in the health care sector, however, is not nearly as prominent. Still, when it is reported that educational choices in schools continue to be very sex-bound, it is mentioned, along with the few girls choosing technical education, that only four percent of boys choose the health care programme (vårdlinje) in upper secondary school (Ltg 35-1979, p. 62). In an explanation of "controlled" work experience orientation in relation to equality between the sexes, another example is shown. It is clarified that girls might try industrial work and the boys might try work in health care (Ltg 47-1975, p. 2-3). Some teachers also encourage younger boys to learn more about health care occupations and girls to show interest in technical jobs (Ltg 14-1977, p. 16).

Another area highlighted in relation to men's non-traditional choices is teaching young pupils. Within the Teachers' Union the low proportion of male school teachers at the junior level is discussed, and in this context "a strong information campaign about junior school teaching directly to the boys who are facing a career choice" is planned (Ltg 9-1975, p. 2). In 1979, the union took up the question of whether it is appropriate to introduce sex quotas in order to get men in junior school teaching. It is a topical issue because a committee of equality between men and women has put forward the suggestion (Ltg 17-1979, p. 30). At the time, the junior school teacher programme is the second-most popular education with over 2000 students applying for 168 seats (Ltg 21-1979, p. 23). Introducing sex quotas would thus make it harder for female students to be admitted. In practice women would have to give way to less qualified men.

\subsection{Addressing Ideas and Notions in Schools and Society}

Equality between the sexes and sex-role thinking often seem as something only concerning pupils. In these discussions teachers and other adults appear to be very equal already. In some contexts, however, the schools' role and values in society are discussed. In an editorial in Teachers' Journal the critical role of teachers and staff in schools is stressed (Ltg 48-1975, pp. 4-5). In the journal there are also demands for the content and pictures in books to be examined concerning sex roles (Ltg 5-1978, p. 16; Ltg 10-1978, pp. 24-25; Ltg 11-1979, pp. 16-18). A reader writes that she has received a large number of books to review, and in these girls hardly exist at all. When girls appear they have been assigned passive roles, such as being a princess who gets rescued by a boy (Ltg 35-1979, pp. 14-15). Another teacher is deeply critical of a textbook on the history of ideas in education. The book has received positive reviews in Teachers' Journal. The critical teacher wonders how it is possible to write a textbook about the history of ideas in education that is not even marginally addressing the attitudes 
towards women during the centuries and the effects they have had on women's education. A textbook excluding half the population and still claiming to be a historical depiction is a matter of self-delusion, she says. The critical teacher highlights the importance of an adequate historical writing as means to understand the contemporary sex-role discussions:

Female pupils of today studying The history of ideas in education will not find any explanations for women's second-rate position. Male pupils will still lack the background of today's sex-role discussions. We are still waiting for the women's history of ideas to be written $(\operatorname{Ltg} 32-1976$, p. 33).

Women's second-rate position, highlighted by the writer above, is also clearly described in other contexts. In the Parliamentary debate a female Member of Parliament stresses the importance of teachers getting education, so that they become aware of the prejudices and traditions that form the basis for discrimination against women. In this connection, it is clearly stated that a male-dominated world is being reflected in schools. The result is that women and women's activities get a concealed place. The Member of Parliament talks about an ideology oppressing women. She also talks about misogynist notions that must be actively addressed in schools. It is the schools' task to educate pupils so that they are able to demand changes in the society outside schools (Minutes May 21, 1976, pp. 78-80).

A group within the National Board of Education too, is stressing the roles of both schools and society. In an issue of Teachers' Journal great scope is given to the programme of equality between the sexes presented by the group. In the programme it is stressed that pupils' sex-role behaviour should be considered a response to adults' expectations and to sex roles within the school system. It is argued that the lack of equality between the sexes is a cultural pattern that must change:

We must become aware that we are part of the problem. We are constantly affecting and shaping our environment, and our fellow human beings, through our own behaviour and attitudes (Ltg 6-1976, p. 27).

In the Government Bills presented in 1979 it is maintained that schools are characterized by the same sex segregation that distinguishes working life in general. The Minister of Schools notes that certain tasks are performed by women and others by men even in schools. In addition, there is a hierarchical pattern in school as well as in society at large. Men have the decision-making positions (Proposition 1978/79:180, p. 18).

In-service training for teachers concerning the sex-role issue is stressed in some discussions. The chair of the Swedish Association of Study and Career Advice says in an interview in Teachers' Journal that a large group of people, even within the school system, believe that current conditions in education and employment are results of biologically-based sex differences. Therefore it is important that all staff within schools get education in sex-role issues (Ltg 6-1976, p. 35). Also in a political context, the teachers' need for education is highlighted. The Minister of Schools writes in the Government Bill of 1976 that the aspiration to achieve equality between men and women is so important, that it should permeate all activities in school. For this to be possible, sex-role matters should be a natural part of all in-service training activities (Proposition 1975/76:39, p. 342).

However, prior to the new national curriculum, LGR 80, it is claimed in Teachers' Journal that there has not been much in-service training about the sex-role issue. A teacher comments that in the curriculum that is still valid, LGR 69; it is stated that schools should promote equality between the sexes and teachers are supposed to address sex-role issues, but it is not easy for teachers to fulfil the demands: "Most of us have received a very modest, if any, education in sex-role issues" (Ltg 19-1980, p. 26; cf. Ltg 6-1977, pp. 16-17). In a letter to the editor, two female teachers call for support in matters concerning equality between the sexes from teacher education. They describe that they are met with opposition and contempt from their male colleagues, if they try to address the issue during an in-service training day or if they suggest relevant literature to be purchased. The men refer to themselves doing the dishes at home and the subject of equality between men and women is considered hackneyed (Ltg 29-1980, pp. 58-59; cf. Ltg 6-1977, p. 16).

\section{Discussion}

According to Connell (2009) gender is characterized by a division into femininity and masculinity. In the discussion in the 1970s, femininity and masculinity were understood as sex roles or sex-role values. It was claimed that no other area was as strongly connected to sex-role values as crafts, i.e. textile craft and woodwork. In this statement the symbolic dimension of gender relations was highlighted, as attention was given to the dichotomous division of crafts into the feminine textile craft linked to softness and the masculine woodwork linked to hardness. The structural dimension referring to the gender division of labour was illustrated when school subjects, education options and career choices were discussed. In the 1970s, just as today, work in the technical area was strongly associated with masculinity. As Berner and Mellström (1997) point out, technical 
skills are important components in the image of the competent man. The optional subject technology was chosen by a large part of the boys, but by hardly any girls. To a great extent the subject was focused on technical training. The technology subject dealt with workshop training and prepared boys for work within traditional industry (Riis, 2001). Similarly, work in the health care sector was, just as today, associated with femininity and attracted mainly girls.

In the material, the wishes and hopes that girls would turn to technical education and technical career choices were highly connected to the issue of equality between the sexes. The female car mechanic and the female industrial worker were put forward as paragons of career choices that were made in the spirit of equality between men and women (cf. Hedlin, 2011). Girls being put forward as mechanics and industrial workers must be understood in relation to the labour market for girls being considered precarious. The female part of the sex-segregated labour market was shrinking since the demand for labour in the healthcare, retail and office was decreasing (Liljeström et al., 1975). In a time when the industry called for more workers, not necessarily car mechanics, the car mechanic nevertheless may be interpreted as a powerful symbol for the Swedish industrial worker, considering the strong position of the car industry in the 1970s. At the beginning of the 1970s Volvo and Saab-Scania were two of the biggest companies in Sweden (Stenlås, 2008). On the one hand, the female car mechanic may seem to be an odd figure to promote, considering cars and car mechanics being highly associated with masculinity (Mellström, 2002; 2004). On the other hand, because of the strong links to masculinity, this vocation was put forward. Showing a female car mechanic sent a clear message saying that gender patterns could and should be challenged.

However, cars and car mechanics being highly linked to symbolic and structural masculinity also had, and still have, consequences in relation to the emotional dimension of gender. Despite the talk and the pictures, not many girls desired to be workers in overalls. Such job choices are not very easily combined with feminine identities (cf. Staberg, 1994). In the empirical material, girls' choices of technology and jobs such as car mechanic are considered choices free of sex-role values; they are referred to as "free" choices. This kind of reasoning is not only Swedish. Cockburn (1991) discussed pupils' choice of occupation on the basis of a British project dealing with girls' and boys' vocational training in the 1980s. Cockburn claims that the talk about free choices was a joke, since everyone knew that making a cross-sex choice had consequences. In her description, the emotions connected to gender norms and the violation of the gender norms, are highlighted. In contrast to a boy, a girl entering an all male workshop would risk mockery, rejection, testing and questioning. In Sweden too, a girl choosing to work as a car mechanic or in the engineering industry would risk questioning and negative treatment At their training, girls making untraditional vocational choices were met with negative attitudes, mockery and sexual harassments from teachers, male classmates and jobsite co-workers (Bergman, 1993; cf. Lennartsson, 2007). The power dimension is implicit in the general starting point that the men and masculine work areas had a norm position and were not expected to change, which shows the hierarchical relation of femininity and masculinity. It may also be noted that the concept "equality between men and women" did not break with the tradition of writing "men" first and "women" second.

In the 1970s the logics of Swedish gender policy-making were characterized by consensus and neutrality (Eduards, 1999; Lindvert, 2007). According to Lindvert (2004) two means for maintaining consensus were, to focus on the labour market, and to frame the issues of gender equality in terms that did not challenge men's interests. This is clearly illustrated in the proposed change in admission rules to upper secondary school giving pupils extra credits for making a non-traditional choice. Firstly, the change in admission rules aimed at bringing change in the labour market. Secondly, boys' interests were not threatened. A girl choosing the workshop training programme (verkstadsteknisk linje) was put forward as an example, in spite of the workshop training being a vocational option that was not very popular. Basically anyone, boy or girl, applying got admitted. In fact, in 1980 the greatest surplus of educational seats was at the workshop training, while the largest deficit of educational seats was in health care training (vårdlinje) (Andrén, 1980). Hence, boys applying for health care training would compete for seats in a very popular vocational education. Only pupils with high credits got accepted and a boy would thus get an advantage. The proposed new rules were implemented and as Jönsson (1992) concludes, they did not influence girls to choose male-dominated programmes. Instead, the rules benefitted boys making female-dominated educational choices.

However, the power dimension of gender relations was referred to by solitary voices such as when the Minister for Schools mentioned a pattern of gender segregation and a hierarchical pattern in school as well as in general, in which men have more powerful positions. Also a Member of Parliament argued that there was a discrimination of women going on in society. Furthermore a textbook which left out women, and literature for pupils excluding girls or picturing them in passive roles, were criticized. Nevertheless, the hierarchical gender 
relations and women's second-rate position were often not highlighted. In general, the focus was on numbers, in getting as many girls as boys in classes and educational choices. The problem of gender inequality seemed to be pupils' attitudes rather than structures and strong cultural norms. Through information and sex-mixed classes the pupils' problematic sex-role thinking would be altered.

Thus, in the material examined, the gender discussions were not very radical. Against this background, how can we understand the recent shift in the Swedish gender equality policy? From a British context Skelton (2010) concludes that earlier decades' focus exclusively on gender binaries, together with a lack of engagement with power dynamics, left a lot of people with a common sense understanding of gender issues. When boys' poor academic performance was highlighted, the assumption was that feminism had gone "too far". This explanation may apply for Sweden as well.

It may also be mentioned that Swedish girls have used their grades more and more for applying for high status education. According to Lindvert (2004) the Swedish gender equality was not to challenge men's interests. As Öhrn (2000) noted it used to be well known that girls as a group performed better in schools than boys as a group Girls did not, however, compete with boys as much as one would expect for high status university education. Still in the 1980s a lot of girls chose typical feminine professions and part-time work (Elgquist Saltzman, 1992). Lately this has changed though. More and more female students apply for prestigious programmes at the university (Högskoleverket, 2008). This led high-status programmes in areas such as medical science, veterinary medicine and law, to start using ways to give priority to male students, for instance, by using forms of gender quotas. However, this obvious discrimination against women was taken to court, and in 2009 it was stated that it was against the law to discriminate against any student applying for education (Centrum för rättvisa, 2009; Högskoleverket, 2008; Krantz, 2010; Strömmer, 2010). Men's interests have thus become threatened, which might have contributed to the new focus on boys and men in Swedish gender equality policy.

\section{References}

Amundsdotter, E. (2010). Att framkalla och förändra ordningen [To induce and change the order]. Stockholm: Gestalthusets förlag.

Andrén, B. (1980). Gymnasieskolan hösten 1979 [Upper secondary school autumn 1979]. Stockholm: Skolöverstyrelsen.

Arnesen, A-L, Lahelma, E., \& Öhrn, E. (2008). Travelling discourses on gender and education: The case of boys' underachievement. Nordisk Pedagogik, 28(1), 1-14.

Baude, A. (1979). Public policy and changing family patterns in Sweden 1930-1977. In J. Lipman-Blumen, \& J. Bernard (Eds.), Sex roles and social policy: A complex social equation (pp. 145-175). London: Sage.

Bergman, B. (1993). “Tjejerna på grabbarnas gymnasielinjer”: En karläggning i tre län ["The girls in guys' programmes at Upper secondary school": Mapping conducted in three counties]. Stockholm: Arbetsmarknadstyrelsen.

Berner, B., \& Mellström, U. (1997). Looking for Mister Engineer: Understanding masculinity and technology at two fin de siècles. In B. Berner (Ed.), Gendered practices: Feminist studies of technology and society (pp. 39-68). Linköping University: Department of technology and social change.

Centrum för rättvisa. (2009). Systematisk könsdiskriminering $i$ den svenska högskolan [Systematic gender discrimination at Swedish universities]. Stockholm: Centrum för rättvisa.

Cockburn, C. (1991). Technology and gender as social constructions: Some implications for education and training. In I. Elgvist Saltzman (Ed.), Education and the construction of gender (pp. 41-47). Umeå University: Centre for Women's Studies.

Connell, R. W. (2009). Gender in world perspective. Cambridge: Polity Press.

Eduards, M. (1999). Toward a third way: Women's politics and welfare policies in Sweden. Social research, 58(3), 677-705.

Egeland, C. (2001). Bergsklättrerskan och de militanta lesbiska feministerna. Om könsbarriärer och jämställdhet inom akademin [The mountain climber and the militant lesbian feminists. About gender barriers and gender equality in academia]. Kvinnovetenskaplig tidskrift, 1, 53-67.

Elgvist Saltzman, I. (1991) The Swedish context concerning gender and education. In I. Elgvist Saltzman (Ed.), Education and the construction of gender (pp. 58-64). Umeå University: Centre for Women's Studies.

Elgqvist Saltzman, I. (1992). Gravel in the machinery or the hub of the wheel? In M. Eduards, I. Elgquist 
Saltzman, E. Lundgren, C. Sjöblad, E. Sundin, \& U. Wikander (Eds.), Rethinking change: Current Swedish feminist research (pp. 61-81). Uppsala: Swedish Science press.

Florin, C., \& Nilsson, B. (1999). "Something in the nature of a bloodless revolution..." How new gender relations became gender equality policy in Sweden in the 1960s and 1970s. In R. Torstendahl (Ed.), State policy and gender system in the two German states and Sweden 1945-1989 (pp. 11-77). Uppsala: Opuscula Historica Upsaliensia.

Foster, V., Kimmel, M., \& Skelton, C. (2001). "What about the boys": An overview of the debates. In W. Martino, \& B. Meyenn (Eds.), What about the boys? Issues of masculinity in schools. Maidenhead: Open University Press.

Hedlin, M. (2011). How the girl choosing technology became the symbol of the non-traditional pupil's choice. Gender and Education, 23(4), 447-459. http://dx.doi.org/10.1080/09540253.2010.490206

Hedlin, M. (2012). Anna Anka i skolan: Att utforska könsdebatter [Anna Anka in school: Exploring gender debates]. In E. Elmeroth (Ed.), Normkritiska perspektiv i skolans likabehandlingsarbete [Norm critical perspectives in school equity work] (pp.45-58). Stockholm: Liber.

Hill, H. (2007). Befria mannen!: Idéer om förtryck, frigörelse och förändring hos en svensk mansrörelse under 1970- och tidigt 1980-tal [Liberate the man!: Ideas on oppression, liberation and change in a Swedish men's movement in the 1970s and early 1980s]. Umeå: Bokförlaget h:ström.

Högskoleverket. (2008). Kvinnor och män i högskolan [Women and men in higher education]. Stockholm: Högskoleverket.

Jönsson, I. (1992). Women in education from a Swedish perspective. In J. Wrigley, (Ed.), Education and gender equality (pp. 49-69). London: RoutledgeFalmer.

Krantz, T. (2010). Positiv särbehandling på högskolan avskaffas [Affirmative action at universities to be abolished]. Dagens Nyheter, 3.

Lennartsson, R. (2007). "Snus under läppen och en massa snuskprat": Maskulinitetsskapande på byggprogrammet ["Snuff under the lip and a lot of dirty talk": Making masculinity in the construction programme] In G. Arvastson \& B. Ehn (Eds.), Kulturnavigering $i$ skolan [Cultural Navigation at School] (pp. 40-51). Malmö: Gleerups.

Lewis, J., \& Åström, G. (1992). Equality, difference, and state welfare: Labour market and family policies in Sweden. Feminist Studies, 18(1), 59-87. http://dx.doi.org/10.2307/3178214

LGR 69. Läroplan för grundskolan 1969 [National curriculum of year 1969. Swedish compulsory school]. Stockholm: Liber.

LGR 80. Läroplan för grundskolan 1980 [National curriculum of year 1980. Swedish compulsory school]. Stockholm: Liber.

Liljeström, R., Fürst Mellström, G., \& Liljeström Svensson, G. (1975). Sex roles in transition: A report on a pilot programme in Sweden. Stockholm: The Swedish Institute.

Lindvert, J. (2004). Spelets regler: Att göra politik av genusfrågor [The rules of the game: Making policy of gender issues]. In C. Florin \& C. Bergqvist (Eds.), Framtiden $i$ samtiden: Könsrelationer i förändring $i$ Sverige och omvärlden [The future in present time: Changing gender relations in Sweden and in the world around us] (pp. 264-289). Stockholm: Institutet för framtidsstudier.

Lindvert, J. (2007). The rules of the game: Organizing gender policies in Australia and Sweden. Social politics, 14(2), 238-257. http://dx.doi.org/10.1093/sp/jxm010

Lundgren, U. P. (1999). Ramfaktorteori och praktisk utbildningsplanering [Frame factor theory and educational planning in practice]. Pedagogisk forskning i Sverige, 4(1), 31-41.

Lundqvist, Å. (1999). Conceptualising gender in a Swedish context. Gender \& History, 11(3), 583-596. http://dx.doi.org/10.1111/1468-0424.00165

Lundqvist, Å., \& Roman, C. (2008). Construction(s) of Swedish family policy 1930-2000. Journal of Family History, 33, 216-36. http://dx.doi.org/10.1177/0363199007313616

Marklund, S. (1983). Skolsverige 1950-1975, del 3, Från Visbykompromissen till SIA [School Sweden 1950-1970, part 3, From the Visby compromise to the SIA Commission]. Stockholm: Liber.

Martino, W., \& Berill, D. (2003). Boys, Schooling and masculinities: Interrogating the 'right' way to educate 
boys. Educational Review, 55(2), 99-117. http://dx.doi.org/10.1080/0013191032000072164

McGee Bailey, S. (1993). The current status of gender equity research in American schools. Educational psychologist, 28(4), 321-339. http://dx.doi.org/10.1207/s15326985ep2804_3

McLeod, J. (1998). The promise of freedom and the regulation of gender - feminist pedagogy in the 1970s. Gender and Education, 10(4), 431-445. http://dx.doi.org/10.1080/09540259820853

Mellström, U. (2002). Patriarchal machines and masculine embodiment. Science, technology, \& human values, 27(4), 460-478. http://dx.doi.org/10.1177/016224302236177

Mellström, U. (2004). Machines and masculine subjectivity: Technology as an integral part of men's life experiences. Men and Masculinities, 6(4), 368-382. http://dx.doi.org/10.1177/1097184X03260960

Nilsson, B. (2008). All vår början bliver svår: Om införandet av ny könsrollsdiskurs i den svenska skolan [To begin is always hard; The introduction of a new gender role discourse in Swedish schools]. In M. Sjöberg \& Y. Svanström (Eds.), Att göra historia: Vänbok till Christina Florin [Making history: A book for Christina Florin]. Stockholm: Institutet för framtidsstudier.

Öhrn, E. (2000). Changing patterns? Reflections on contemporary Swedish research and debate on gender and education. NORA - Nordic Journal of Feminist and Gender Research, 8(3), 128-136. http://dx.doi.org/10.1080/080387400750054360

Pringle, K. (2009). Future research on gender equality in the Scandinavian countries. In K. Melby, A. B. Ravn, \& C. Carlsson Wetterberg (Eds.), Gender equality and welfare politics in Scandinavia: The limits of political ambition? (pp. 223-229). Bristol: Polity press.

Riis, U. (2001). The history of the technology subject in the Swedish 9-year comprehensive school. In T. Ginner (Ed.), PATT 1996. Proceedings from the conference Pupils' Attitudes Towards Technology (pp. 69-71). Linköping University Electronic Press. Retrieved from http://www.ep.liu.se

Sjögren, J. (2003). Ordination: Vardagsfeminism [Prescription: Everyday feminism]. Stockholm: Bokförlaget Dagens Nyheter.

Sillén, I., Schmitz, E., Lindqvist, E., \& Almroth, V. (2010). Minnen från 70-talets kvinnokamp [Memories from the women's movement of the 1970s]. Stockholm: Migra förlag.

Skelton, C. (2010). Gender and achievement: Are girls the "success stories" of reconstructed education systems? Educational Review, 62(2), 131-142. http://dx.doi.org/10.1080/00131910903469536

SOU 2005:66. Makt att forma samhället och sitt eget liv [The power to form society and your own life]. Stockholm: Fritzes.

Staberg, E-M. (1994). Gender and science in Swedish compulsory school. Gender and education, 6(1), 35-45. http://dx.doi.org/10.1080/0954025940060103

Stenlås, N. (2008). Technology, national identity and the state - the rise and decline of a small state's military-industrial complex. Stockholm: The Royal Institute of Technology.

Strömmer, G. (2010). Så lyckades vi förbjuda den orättvisa könskvoteringen. Newsmill [That is how we managed to prohibit the unfair gender quotas ]. Retrieved from http://www.newsmill.se

Towns, A. (2002). Paradoxes of (in) equality: Something is rotten in the gender equal state of Sweden. Cooperation and conflict: Journal of the Nordic International Studies Association, 37(2), 157-179.

Utbildningsdepartementet. (2012). Jämställdhet för både kvinnor och män. Pressmeddelande 28 September 2012. [Gender equality for both women and men. Press release. September 28, 2012]. Retrieved from http://www.regeringen.se/sb/d/15615/a/200410

Wahl, A., Eduards, M., Holgersson, C., Höök, P., Linghag, S., \& Rönnblom, M. (2008). Motstånd och fantasi: Historien om $F$ [Resistance and fantasy: The history about F]. Lund: Studentlitteratur.

Weiner, G. (2005). Bilateral vision. Gender and education in the United Kingdom and Sweden. European Education, 36(4), 22-39.

Zyngier, D. (2009). Doing it to (for) boys (again): Do we really need more books telling us there is a problem with boys' underachievement in education? Gender and Education, 21(1), 111-118. http://dx.doi.org/10.1080/09540250802580844 


\section{Appendix}

The Empirical Material

- SOU 1974:53, Skolans arbetsmiljö. Betänkande avgivet av utredningen om skolans inre arbete. [The Work Environment of Schools. Report delivered by the Committee on inner work of schools]. Stockholm: Statens Offentliga Utredningar [Swedish Government Official Reports].

- Proposition 1975/76:39, Om skolans inre arbete m.m. [Government Bill to the Parliament On the Inner Work of Schools].

- Parliamentary motions 1976 to The Swedish Riksdag.

- $\quad$ Minutes of the ensuing parliamentary debates: The Swedish Riksdag May 21, 1976.

- Proposition 1978/79:180, Om läroplan för grundskolan m.m. [Government Bill to the Parliament on the National Curriculum of the compulsory school system and more].

- Parliamentary motions 1979 to The Swedish Riksdag.

- Minutes of the ensuing parliamentary debates: The Swedish Riksdag June 5, 1979.

All the follow-up motions (i.e. Parliamentary motions brought by reason of the specific bills) have been examined.

- Lärartidningen (Ltg) Teachers'Journal, 1975-1980. The journal was generally published weekly. 